\title{
Burnout in Completing Undergraduate Thesis and Its Implications to Guidance and Counseling Program
}

\author{
Kurnia Sari* \\ Guidance and Counseling \\ The Faculty of Education \\ University of PGRI Palembang \\ Palembang, Indonesia \\ kurniasari@univpgri-palembang.ac.id*
}

\author{
Syska Purnama Sari \\ Guidance and Counseling \\ The Faculty of Education \\ University of PGRI Palembang \\ Palembang, Indonesia \\ syskapurnamasari@univpgri-palembang.ac.id
}

\begin{abstract}
Burnout for final semester students couldn't be considered trivial. Someone experiencing burnout activities will be hampered, as well as a trigger for the emergence of disease either physical or psychic. The objective of this study was to identify the condition of the student burnout level in completing their undergraduate thesis and its implications for guidance and counseling program in University of PGRI Palembang. This research is quantitative research with a quantitative descriptive analysis method. The population of the research is 69 people, the sample is selected by random sampling, used the formula Slovin, and gained 58 people as samples. Data analysis used frequency distribution, percentage formula and the interpretation of the score. The highest score of students is on the moderate category, with $\mathrm{fi}=$ 37 , equivalent to the value of $P=63.8 \%$ and the rest is at a low and high level. Hence the necessary for preventive and curative efforts of relevant parties in particular university institutions in which there is a Pusat Bimbingan dan Pengembangan Karir (PBPK), which maintained by guidance and counseling Program in University of PGRI Palembang.
\end{abstract}

Keywords-burnout, thesis completing

\section{INTRODUCTION}

Skripsi (undergraduate thesis) is a mandatory task to do student, as a condition for finishing their study period. In addition to the demands of the lecture, a student's final grade should immediately resolve their undergraduate thesis also due to pressure from parents who expect them very soon graduated. But in fact, many students find difficulties in completing a thesis. The final grade students in General in the age range 20-23 years is located in the period of early adulthood, as individuals who are in the period of early adulthood, they are expected to hold the adjustment process itself against the completion of the thesis independently. Hurlock [1] says early adulthood was difficult because, during this period, they are expected to be self-sufficient. When they find difficulties overcome, they hesitate to ask for helping and advising to others because it is reluctant in the case they are considered immature.

Based on Agustin Research [2] student's obstacles in resolving the thesis, a student having trouble finding sources of learning, the difficulty met professors to consult, the difficulty adjusting to the learning environment, do not understand the material that was provided by lecture, a lot of the cost for the task, the difficult to refuse a friend when studying, having problems with academic lecture, having personal problems with lecturers, having personal issues with friends, many family problems, many problems in place of cost, having difficulty in translating foreignlanguage books, difficulty in making the studying task, and the difficulty of time distribution with the bustle outside the study.

As the youth generation, they will face difficulties with wistfulness, although in reality they require parents, friends, teachers, and their circle to be able to help them cope with their difficulties. The difficulties that they will face the pressure and resulting stress. The results of Broto research [3] shows the stress that occurs undergraduate student in completing thesis because they are not able to deal with the difficulties encountered in completing thesis. The stress experienced by individuals in a continuing and not to be done the proper coping can lead to burnout. Cooper [4] states burnout can occur due to stress sustained in work/services.

Pines and Aronson [5] burnout is physical, emotional, and mental fatigue caused by long-term involvement in situations that are full of emotional demands. The fatigue can be seen from the behavior of someone who is experiencing burnout. Cooper [4] states burnout can occur due to ongoing stress in work/ service. Although students in general have not worked, but they have obligations that must be done, namely carrying out the obligation to complete assignments as students. According to Rahmawati [6] students are considered to work because they are involved in structured activities, such as attending classes and doing work assignments with specific goals.

Burnout is a syndrome that consists of three dimensions, namely emotional exhaustion, depersonalization and low self-esteem, Maslach [7]. The three dimensions of burnout above are mostly found in final year students who get a lot of final assignment pressure, namely thesis. According to Goliszek [8] burnout can be classified into four stages. The first stage is idealism 
and high expectations. The second stage is pessimism and early work dissatisfaction. Third step, back off and isolate yourself. The fourth stage, cannot turn around and lose interest.

Cherniss [9] argues burnout is a form of withdrawal psychologically in responding to stress that excessive or against the insurrection. Burnout is a factor that causes a decrease in the quality of academic students. Students who have experienced Burnout in completing a thesis will attempt to withdraw from the neighborhoods that are associated with the campus and academic quality so that the thesis will also decrease which will cause academic failure.

Weiner [10] found that academic failure can lose confidence, mastery orientation, and make a negative reaction. One of the negative reactions caused by the student may be suicidal. For example, a Sriwijaya University students found dead from apparent suicide causes stress in completion thesis (Komering Online, 20th March 2018), then on 24th December 2018, the same incident held in Padjajaran University (Detiknews, 24th December 2018).

Based on such phenomena can be known that burnout for undergraduate students who are working on thesis cannot be taken for granted because it will impact badly on students. As researchers interested in examining the behavior of burnout on the final grade students in completing a thesis for guidance and counseling program in University of PGRI Palembang.

\section{METHODS}

The research used a quantitative approach, with quantitative descriptive method. The objective of this study was to describe the condition of the final grade student burnout level in completing the thesis quantitatively. Description of burnout obtained through data processing based on the acquisition of the Burnout scale score.

The population in this research is 69 student's guidance and counseling program in University of PGRI Palembang were on 8th semester 2015-2016. 58 students were selected as the sample, based on the slovin formula calculation.

The research used burnout scale, with 40 items by using a Likert scale model. Data analysis techniques used formula for distribution of frequency and percentage. In this study, the data presented in the form of a table of frequency distribution and percentage.

\section{RESULT}

The results showed student's score based on the earnings scale burnout in completing a thesis is the highest on the criteria moderate, with $\mathrm{f}_{\mathrm{i}}=37$, equivalent to $\mathrm{P}=$ $63.8 \%$ (Figure 1)

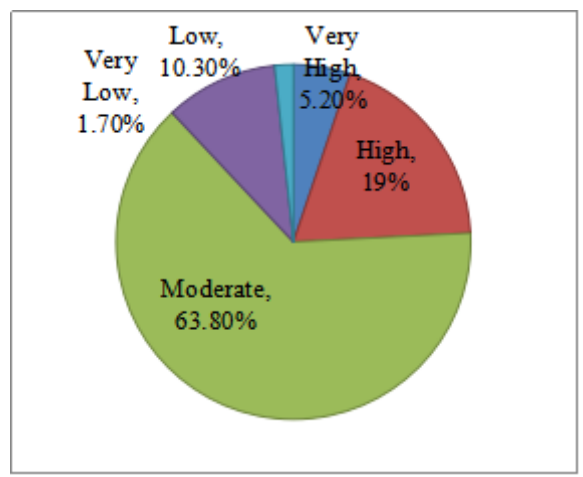

Fig.1. The Percentage of Level Burn Out in Completing Thesis

The description of criteria and frequency distribution score of Burnout in completing thesis scale $(\mathrm{N}=58)$ can be seen in table 1 .

Table 1. Criteria and frequency Distribution Score of Burn Out in Completing Thesis Scale $(\mathrm{N}=58)$.

\begin{tabular}{|l|c|l|c|c|c|}
\hline No & Interprestasi & $\begin{array}{l}\text { Rentangan } \\
\text { skor }\end{array}$ & f & $\%$ & $\begin{array}{c}\text { Rata-Rat } \\
\text { a }\end{array}$ \\
\hline 1 & Sangat Tíngg & $159<\mathrm{X}$ & 3 & 5,2 & \\
\hline 2 & Tingg & $133<\mathrm{X} \leq 159$ & 11 & 19 & \\
\hline 3 & Sedang & $107<\mathrm{X} \leq 133$ & 37 & 63,8 & 125,7241 \\
\hline 4 & Rendah & $81<\mathrm{X} \leq 107$ & 6 & 10,3 & \\
\hline 5 & Sangat & $\mathrm{X} \leq 81$ & 1 & 1,7 & \\
& Rendah & & & & \\
\hline & & & 58 & $100 \%$ & \\
\hline
\end{tabular}

Any result shows a majority of the student's guidance and counseling program $(\mathrm{P}=83 \%)$ experienced physical exhaustion, with $\mu=48$ and $\Sigma X=2784$. $70 \%$ students experienced mental exhaustion with $\mu=40.85$ and $\Sigma \mathrm{X}=$ 2369. Lack of motivation experienced by $29 \%$ students, with $\mu=17$ a and $\Sigma X=984$. The third sub-variables shows a moderate level of burnout. On the other hand, sub variable emotional exhaustion belongs to a high level, with $\mathrm{P}=32 \% \quad \mu=18.53$ and $\Sigma \mathrm{X}$ amounted to 1075 . The details of each sub-variables can be seen in table 2 . 
Table 2. Frequency Distribution Response Based on Sub variable Burnout $(\mathrm{n}=58$.)

\begin{tabular}{|l|l|l|l|l|l|l|l|l|l|}
\hline No & Sub & \multicolumn{7}{|c|}{ Skor } & \\
\cline { 3 - 9 } & Variables & ideal & $\max$ & $\min$ & $\Sigma$ & $\mu$ & $\%$ & sd & level \\
\hline 1. & $\begin{array}{l}\text { Kelelahan } \\
\text { Emosi (5) }\end{array}$ & 25 & 25 & 7 & 1075 & 18,53 & 32 & 3,475 & $\mathrm{~T}$ \\
\hline 2. & $\begin{array}{l}\text { Kelelahan } \\
\text { Fisik (15) }\end{array}$ & 75 & 70 & 27 & 2784 & 48 & 83 & 9,277 & $\mathrm{~S}$ \\
\hline 3. & $\begin{array}{l}\text { Kelelahan } \\
\text { kognitif (14) }\end{array}$ & 70 & 61 & 18 & 2369 & 40,85 & 70 & 8,053 & $\mathrm{~S}$ \\
\hline 4. & $\begin{array}{l}\text { Kehilangan } \\
\text { motivasi (6) }\end{array}$ & 30 & 28 & 7 & 984 & 17 & 29 & 4,683 & $\mathrm{~S}$ \\
\hline
\end{tabular}

\section{DISCUSSION}

The results showed that most students of guidance and counseling program in academic years $2015^{\text {th }}$ and $2016^{\text {th }}$ are being burnout at a moderate level. The situation is not too worrying, but if there is no responsive action, it will be a boomerang for themselves, because it would be complicated to accomplish their study process. Many students who could not avoid burnout behavior while working on a thesis. According to Freudenberger and Maslach [11], that burnout occurred in conditions of social relationships are changing rapidly.

As the last semester students, they are required to be able to work on a thesis independently. Students are no longer together with his classmates, he should be able to interact with students from different classes to consult with the same lecturer, therefore requires good adaptability. Besides, a new habit appears, they must ready and good preparation in facing the lecturer and are required to mastery a wide range of theories from various reference sources.

Burnout can be triggered by situational factors, one of which is the event that is full of pressure and pressure in doing the work Allarcon [12]. The pressures and demands of students usually come from self, family, friends and theses promotor. The pressure and demands of the quickly can improve the behavior of burnout because it causes the student to become physical exhaustion due to lack of nutritional intake, lack of rest and can cause mild to severe stress. According to Bakker, Demorouti, and Euwema [13], feedback, social support, and good working relationships are part of job resources that can decrease levels of burnout. Students need support and guidance from their circle.

To bring down the risk of burnout is from personal and social support from family, colleagues, and theses promotor is needed. Students who feel lack of confidence are less effective. Ironically, they are like thinking about failure. Maslach [11] states that the reduced quality of self is caused by feeling guilty about having done others around them negatively, for example someone who changes his behavior to be bad in front of others because he does not pay attention to his own needs and body condition. According to Hikmatullah [14] by knowing the condition of the body in person, the subject is expected to be able to cope with burnout, by opening up, consulting or setting priorities in order to carry out each activity in order to avoid the symptoms of burnout and to prioritize health so that it can continue to work more productively for a period of time the long one.

Social support may be either a sense of being loved, cared for, respected or rewarded his closest people so that students feel comfortable and protected. According to Havighurst [15], the family is the closest neighborhood that forms a special bond that can prevent them from fear, anxiety when facing failure in academic assignments

According to Bandura [16], the individual directed with suggestions, advices, and guidances could enhance its ability assets to help the individual achieve the desired goals. Social support from influential mentors lecture, for example, by providing scheduled thesis consultation, establish good communication when giving advice, the advice associated with the thesis a student thesis guidance during the process. Furthermore, the role of friends' colleagues should also note in reducing burnout behavior. Thus a colleague's friend can give you some positive effects when students can make friends with people who have a high motivation to complete his education. Students will be encouraged and the spirit as well as mutual helphelp, to make the graduation together.

Undergraduate student burnout behavior problem is the responsibility of the organizational center for career guidance and development (PBPK) in University of PGRI Palembang on collaboration with the Guidance and Counseling Study Program. The implication of the results of this study is expected to be able to be used by PBPK and the Guidance and Counseling Study Program as data to facilitate the making of Counseling service work programs in dealing with burnout behavior problems both preventive and curative. Preventive can be done by providing information services about the behavior of burnout when thesis training activities are carried out, so that students can understand and anticipate independently.

Furthermore, curative countermeasures are given the need for burnout assessment. The next action was the provision of Guidance and Counseling services, both classically in groups and individually conducted by the Guidance and Counseling Study Program lecturers in University of PGRI Palembang. Preparation of work programs in accordance with needs analysis is expected to reduce burnout behavior in the guidance and counseling study program.

\section{CONCLUSION}

Research shows that the largest score the first students is on the criteria moderate, with a total frequency of 37 respondents, equal to $63.8 \%$. The second score is most on the high criteria, with the frequency of the 11 respondents equal to $17 \%$. The third score is most on the criteria of low frequency, with 6 respondents equal to $10.3 \%$. The fourth score is most on the criteria that is very high, with a frequency of 3 responded equally to $5.2 \%$. The fifth score is most on high criteria, with a frequency of 1 responded equal to $1.7 \%$. The research findings that student burnout in completing thesis must be controlled and not to increase to high level. 


\section{REFERENCES}

[1] Hurlock, E. B. (1999). Psikologi Perkembangan: Suatu Pendekatan Sepanjang Rentang Kehidupan. Alih Bahasa: Istiwidayati \& Soedjarwo. Edisi Kelima. Jakarta: Erlangga.

[2] Agustin, M. (2009). Model Konseling Kognitif- Perilaku Untuk Menangani Kejenuhan Belajar pada Mahasiswa (Disertasi). Bandung: Universitas Pendidikan Indonesia.

[3] Broto, H.D.F.C (2016). Stress pada Mahasiswa Penulis Skripsi. (Skripsi). Yogyakarta: Universitas Sanatha Dharma.

[4] Dewe, P. (2004). Job Stress and Burnout. Journal of Applied Psychology, 2: 475-489.

[5] Rahmawati, Z. (2015). The Study of Academic Burnout in Students with High and Low Level Of Self-Efficacy. Procedia - Social and Behavioral Sciences, 171: 49 - 55.

[6] Maslach, C. (1993) Burnout: A Multidimensional Perspective. Professional Burnout: Recent Developments in Theory and Research. Taylorand Francis, Washington DC, 19-32.

[7] Lamria, E., \& Monalisa, S. (2009). Faktor-Faktor yang Mempengaruhi Kejadian Burnout pada Perawat Pelaksana di RS PGI Cikini Jakarta. (Naskah Publikasi). Fakultas IImu Keperawatan Universitas Indonesia.
[8] Cherniss, C. (1980). Staff Burnout (Job Stress In The Human Services). London: Sage Publications Ltd.

[9] Weiner, B. (1990). "History of Motivational Research in Education". Journal of Educational Psychology, 82: 416-422.

[10] Maslach, C. \&M. Leiter. (2008). Early Predictors of Job Burnout and Engagement. Journal of Applied Psychology, 93: 498-512.

[11] Allarcon, G.M. (2011). A Meta Analysis of Burnout with Job Demand Resources and Attitude. Journal of Vocational Behavior, 79: 549-562.

[12] ] Bakker, A. B. E. Demerouti, \&M.C. Euwema. (2005). Job Resources Buffer the Impact of Job Demands on Burnout. Journal of Occupational Health Psycholog, 10: 170-180.

[13] Hikmatullah, F. (2016). Hubungan Employee Engagement dan Burnout Pada Karyawan Divisi IT. Jurnal Ilmiah Psikologi, 9(1) : 100-108.

[14] Mönks, F. J., Knoers, A. M. P., \& Haditono, S. R. (1998). Psikologi Perkembangan. Yogyakarta: Gadjah Mada University Press.

[15] Bandura, A. (1986). Social Foundations of Thought and Action. Englewood Cliffs, NJ: Prentice Hall. 